\title{
Family ties of crack cocaine users cared for in a psychiatric emergency department
}

\author{
Maycon Rogério Seleghim ${ }^{1}$ \\ Sônia Regina Marangoni² \\ Sonia Silva Marcon² \\ Magda Lúcia Félix de Oliveira ${ }^{3}$
}

This study characterizes the family ties of crack cocaine users cared for in a psychiatric emergency department in southern Brazil. It is a qualitative study with a series of cases carried out in the city of Maringá, PR, Brazil from April to June 2010. Data were collected through semi-structured interviews, analyzed using content analysis, and organized into two categories: family ties as facilitators in the use of crack cocaine and other drugs; and fragmented family ties of crack users. Loss of relational bonds with family and social milieu was observed among the ten studied users in addition to the presence of drugs and violence in the family sphere. Further studies addressing the use of crack and its interface with the family are encouraged, taking into consideration that families have an essential role in the initiation and continuity of drug use.

Descriptors: Family Relations; Street Drugs; Crack Cocaine; Emergency Services Psychiatrics.

${ }^{1}$ RN, Master's student, Universidade Estadual de Maringá, PR, Brazil. E-mail: Maycon - mseleghim@yahoo.com.br, Sônia - sonia.marangoni@yahoo.com.br.

2 RN, Ph.D. in Nursing Philosophy, Associate Professor, Departamento de Enfermagem, Universidade Estadual de Maringá, PR, Brazil. E-mail: soniasilva.marcon@gmail.com.

${ }^{3}$ RN, Ph.D. in Public Health, Assistant Professor, Departamento de Enfermagem, Universidade Estadual de Maringá, PR, Brazil. E-mail: micoleao@wnet.com.br.

Corresponding Author:

Maycon Rogério Seleghim

Rua Osvaldo Cruz, 340, Apto. 309

Bairro: Zona 07

CEP: 87020-200, Maringá, PR, Brasil

E-mail: mseleghim@yahoo.com.br 


\section{Vínculo familiar de usuários de crack atendidos em uma unidade de emergência psiquiátrica}

O objetivo deste estudo foi conhecer o vínculo familiar de usuários de crack, atendidos em uma unidade de emergência psiquiátrica do Sul do Brasil. Trata-se de pesquisa qualitativa, com delineamento de série de casos, realizada no município de Maringá, PR, no período de abril a junho de 2010. Para a coleta dos dados utilizou-se roteiro semiestruturado de entrevista. Os dados foram analisados seguindo a técnica de análise de conteúdo e organizados em duas categorias: o vínculo familiar como facilitador do uso de crack e outras drogas, e o vínculo familiar fragmentado de usuários de crack. Entre os dez usuários investigados, evidenciou-se a perda dos vínculos relacionais com a família e o meio social, presença de drogas e violência no ambiente familiar. A realização de pesquisas sobre o uso de crack e sua interface com a família deve ser estimulada, visto que as famílias possuem papel fundamental na iniciação e continuidade ao uso de drogas.

Descritores: Relações Familiares; Drogas Ilícitas; Cocaína Crack; Serviços de Emergência Psiquiátrica.

\section{Vínculo familiar de usuarios de crack atendidos en una unidad de emergencia psiquiátrica}

El objetivo del estudio fue conocer el vínculo familiar de usuarios de crack atendidos en una Unidad de Emergencia Psiquiátrica del Sur de Brasil. Se trata de una investigación cualitativa, con delineamiento de serie de casos, realizada en el municipio de Maringá, en Paraná, en el período de abril a junio de 2010. Para la recolección de datos se utilizó un guión semiestructurado de entrevista. Los datos fueron analizados siguiendo la técnica de análisis de contenido y organizados en dos categorías: el vínculo familiar como facilitador del uso de crack y otras drogas, y el vínculo familiar fragmentado de los usuarios de crack. Entre los diez usuarios investigados, se evidenció: pérdida de los vínculos relacionales con la familia y con el medio social y, presencia de drogas y violencia en el ambiente familiar. La realización de investigaciones sobre el uso de crack y su interfaz con la familia deben ser estimuladas, ya que las familias poseen un papel fundamental en la iniciación y continuidad del uso de drogas.

Descriptores: Relaciones Familiares; Drogas Ilícitas; Cocaína Crack; Servicios de Urgencia Psiquiátrica.

\section{Introduction}

The consumption of crack cocaine is considered an emerging public health problem. The first records of its introduction in Brazil date from the end of the 1980s; an increasing prevalence in its use has been observed since then ${ }^{(1)}$.

The complexity that involves the phenomenon of crack consumption and the fact of its consequences affect users, families and society, with a consequent increase in violence, indicate the need for further studies addressing the multiple aspects of the theme to contribute to the development of public policies specific to controlling and treating it(2).
Crack is a byproduct of cocaine, a substance extracted from leafs of a plant with the scientific name Erythroxilon coca, found in countries of South and Central America, and is a paste mixed with sodium bicarbonate(3). Its main characteristics include a powerful rewarding effect of short duration, which encourages repeated consumption in such a way that it triggers intense and compulsive use after experimentation, playing a central role in the user's life; it becomes a priority to the detriment of previously relevant behaviors ${ }^{(1-2)}$.

Because of an urge, an uncontrollable desire to use the drug, users report selling their belongings and those 
of their families, robbery, kidnappings, activities linked to trafficking and female or male prostitution, which, given numerous sexual partners and low prevalence of the use of condoms, has exposed users to the risk of sexually transmissible diseases and $\mathrm{HIV}^{(4)}$.

The compulsive use of crack interferes in the individual dimension of users, compromising their social relationships in such a way that stable and normalized social and family bonds become fragile or are ruptured, which progressively marginalizes these individuals ${ }^{(2,4)}$.

Considering that the factors that lead one to use drugs or not are mainly influenced by one's sociocultural context, the family is an extremely important element influencing its members' decision concerning initiating the use of drugs and maintaining $i^{(5)}$.

In social terms, the family is a basic unit in the construction and development of the individuals who compose it, transmitting values, rules, costumes and ideas to generations in addition to models and standards of behavior, including those harmful to health(6-7). The existence of healthy relational bonds among individuals and families, such as the delimitation of responsibilities, support and family affection, are indicated as protection factors $^{(5)}$

In general, the role of the family can be understood based on three main loci. The first refers to the centrality of families as a factor of social protection, which implies being active and participating in processes of change; the second highlights that the family can, paradoxically, either nurture or destroy, give identity to the individual or cause him/her to disintegrate; and the third refers to its importance in promoting and maintaining the health of its members ${ }^{(8)}$.

Authors point to the important role of family relationships in influencing the use of drugs since neglect, abandonment and lack of care are considered a form of family violence, expressed by the absence, refusal or lack of care required by someone who should receive $\operatorname{care}^{(9)}$.

Based on the assumption that bonding is related, among other factors, to the interaction of individuals with the family, the use of drugs can also be understood from this perspective. Research addressing contextual facts, risk and protection related to the family environment, is relevant to understanding the use of drugs, and therefore, is required because it can contribute to the implementation of effective preventive actions ${ }^{(5)}$.

Therefore, this study identifies the family bonds of crack users cared for in a psychiatric emergency department in the South region of Brazil.

\section{Method}

This qualitative case-series study was carried out between April and June, 2010. A case-series analysis consists of a description of a group of ten or more individuals with a disease or problem, while a retrospective analysis of these individuals' lives is common ${ }^{(10)}$.

The investigated cases originated from a psychiatric emergency department at the Maringá City Hospital, a public facility characterized as a general hospital of medium complexity and a referral center for psychiatric emergencies and hospitalizations for the 67 cities composing the three health regional agencies in Paraná: the $11^{\text {th }}$ Regional Agency (Campo Mourão), $13^{\text {th }}$ (Cianorte) and $15^{\text {th }}$ Regional Agencies (Maringá).

The list of inpatients was used to select the participants and the medical files of those selected were consulted in order to establish the reasons that led users to seek the psychiatric emergency department.

The composition of the studied cases was based on qualitative representativeness, called an intentional sample ${ }^{(11)}$. All the crack users hospitalized in the unit on the days of data collection and who met the following inclusion criteria were interviewed: being 18 years old or older and in sound mental and clinical condition to answer the data collection instrument according to the health team's evaluation. A total of 12 users, both genders, were interviewed though two were excluded from the study (one was a minor and the other denied being a crack user). Hence, the sample was composed of ten users.

The users were initially afraid to participate in a study addressing the use of drugs, especially one focusing on crack. Such a fact required a greater effort in clarifying the study's objectives, an opportunity taken by the interviewer to bond with the participants. The individuals consented to the interviews after the researchers' initial approach and after their doubts were clarified, especially in relation to the confidentiality of information provided.

The interviews were individually held in a reserved place at the unit itself and took an average of one hour. Two researchers participated of all the interviews: one responsible for conducting the interview and the other for taking notes. Given the specificity of the studied population, interviews were not tape-recorded but the testimonies were fully recorded on the interview script. It is worth noting that notes taking during the interview were read to the participants after each interview so 
that they could confirm, complete or even change what they had initially reported.

The interview script was developed by the researchers themselves. It included semi-structured interview questions and was composed of two parts: one addressed the participants' socio-economic and demographic information and also that related to crack and other drug use; the second part was composed of open questions aiming to investigate aspects of the family environment and bonds.

Thematic content analysis was used to analyze the collected data. Thematic analysis consists of uncovering core meanings that compose a communication whose presence or frequency means something to the intended objective. It encompasses a pre-analysis phase, exploration of material, treatment of the obtained results and interpretation ${ }^{(12)}$. For that, the interviews were exhaustively read and then data were organized into two categories.

The study project was authorized by the Maringá Health Department and was approved by the Ethics Committee Concerning Research with Human Subjects at Maringá State University (protocol No. 291/10). All guidelines and standards provided by Resolution 196/96, National Council of Health, were complied with, including free and informed consent forms signed in two copies.

To ensure the confidentiality of the participants' names, they are identified by the letter "I" following by Arabic numerals according to the sequence of interviews.

\section{Results}

Most of the studied crack users were men, age ranging from 20 to 49 years old, with a greater occurrence among those from 20 to 27 years old. Dropping out of school was observed in all cases; almost all the individuals had reached at most incomplete secondary school and only one of the interviewees had higher education, though incomplete (Figure 1).

None of the participants had, at the time of the interview, stable loving relationships while a large share was separated with children. Only one of the interviewees had a formal job and three were homeless.

\begin{tabular}{|c|c|c|c|c|c|c|}
\hline Users & Gender* & Age & Schooling & Marital Status & $\begin{array}{c}\text { Number of } \\
\text { children }\end{array}$ & Current occupation \\
\hline 11 & Woman & 37 & Incomplete secondary school & Separated & 4 & Homeless \\
\hline 12 & Woman & 20 & Incomplete primary school & Separated & 1 & Homeless \\
\hline 13 & Man & 20 & Incomplete secondary school & Single & - & Unemployed \\
\hline 14 & Man & 25 & Incomplete primary school & Separated & 1 & Homeless \\
\hline 15 & Man & 49 & Incomplete secondary school & Single & - & Painter \\
\hline 16 & Man & 27 & Incomplete primary school & Single & - & Unemployed \\
\hline 17 & Man & 31 & Incomplete secondary school & Separated & - & Unemployed \\
\hline 18 & Man & 35 & Incomplete secondary school & Separated & 3 & Unemployed \\
\hline 19 & Man & 23 & Incomplete Higher School & Single & - & Forklift Operator \\
\hline 110 & Woman & 42 & Incomplete primary school & Separated & 2 & Unemployed \\
\hline
\end{tabular}

Figure 1 - Distribution of crack users according to socio-economic and demographic data. Maringá, PR, Brazil, 2010

Duration of crack use ranged from two to 17 years though most had used it less than eight years. Daily use was the most reported, compulsive use is observed and is characterized by the participants "as much as I have".

Most initiated the use of drugs with alcohol and/or cigarettes and all reported crack as the last drug in use. Age in which the use of legal or illegal drugs was initiated ranged from 11 to 17 years old. The involvement with illegal activities to acquire crack was also verbalized by them as well as selling some of their belongings and/or that of their families.
The reasons that led users to seek a psychiatric emergency department were: they spontaneously sought the service to treat dependency caused by crack (I1, I2, I8 and I10); history of aggressiveness with the family (I3 and I5); referred from the emergency department after clinical treatment (I6 and I7); signs and symptoms of mental disorders at the time they sought care (I4 and I9).

After exhaustive reading of records, data were grouped into two thematic categories: family bonds as facilitator to the use of crack cocaine and other drugs, and fragmented family bonds of crack users, which are presented as follow: 


\section{Family bonds as facilitator to the use of crack cocaine}

In this category we observed the presence of some characteristics related to family bonds considered favorable to initiating and continuing the use of drugs.

The use of legal and/or illegal drugs by one or more family members was reported by crack users, an evidence of an implicit family culture of drug use disseminated among the nuclear family and associated with violence and social rupture. My family was big, I have six siblings, one is dead, we fought, discussed, not because of drugs, they drunk (I5). My sister used paint thinner and glue, she's married now, I don't know if she uses still (I2). [...] my sister smoked marijuana (I1). Everybody smoked and drunk (I8).

In relation to the presence of interfamily violence, characterized by the interviewees as arguments and discussions, great part of the users verbalized repressive attitudes on the part of their families in relation to the use of crack such as home confinement and complaining to the police. I run away [...] I discuss, they say they'll commit me (I2). There was much conflict, my father tried to kill my mom because of drinking (I10).

The testimony of one of the users drew our attention. She reported a specific type of interfamily violence: child sexual abuse committed by close relatives within her own home. [...] I'd only stay when my mom was at home so I'd not be abused by my brother (I10).

The users who were separated frequently reported the occurrence of relational conflicts with their spouses due to the use of crack characterized by misunderstandings and quarrels, who would constantly demand that they stop using drugs. She (wife) would fight, I'd stay 'till late on the streets, spending my salary [...], she couldn't take it anymore and left home (I4). We'd fight before because I drunk then it got worse because I started using crack (I7). She'd tell me to stop it (I8). Sometimes he'd (husband) let me get drunk, stoned, so he could go out and leave me with the kids (I10).

\section{Fragmented Family bonds of crack users}

Few of the participants still live with their parents. Marriage was the most common reason for leaving the parents' home, most married during adolescence. One of the users reported a pregnancy and the other reported sexual abuse as the reasons that forced them to leave their family's home.

Some reported they currently have no contact with their parents and many of them reported a good relationship with their parents, though we observed in the participants' medical files that hospitalization was a consequence of them being aggressive with their families.

Testimonies referring to affection and support from the family in relation to the drug problem are observed among the users who reported having a good relationship with their parents, diverging from the motive for hospitalization: [...] thank God, they (parents) provide support for me to abandon crack (I3). I don't have family conflicts, I trigger the conflict because of the drugs (I9). They (family) tried to help, but I'm the one who has to help (I3). I have good relationships, everyone is good to me, support me to leave the drugs (19).

Many of those who were separated from their spouses used crack even before getting married. Two users reported the use of crack and other drugs with their spouses in their family environment while they also had children. He (husband) sold the stone (crack) and we'd enjoyed it together (E10). Me, him (husband) and his brother smoked together (E2).

In relation to current relationship of users with spouses and children, we observed relational ruptures of users with their spouses; none reported any contact with their former partners. One of the users had recently separated, about two months before the interview.

We also observed that the participants kept little contact with children and most of the participants visited them only once a week. Only one user lives with her son and she has been diagnosed with schizophrenia.

\section{Discussion}

The profile of crack users revealed in this study is similar to that described in the literature. The profile of Brazilian users is a young man, with a low educational level, not formally employed(13). The presence of young users or early young adults is a marking characteristic of the phenomenon 'crack', which presents use more associated with disruptive processes in relation to social life. A low level of schooling implies, among other aspects, less inclusion in the formal job market, lower financial availability, and consequently greater social vulnerability.

Even though crack is relatively recent in the Brazilian context, some of the interviewees initiated its use only a few years after the first records of crack in the country, showing rapid aggregation and dissemination of the drug in the country. Added to this, an increase was observed from 2001 to 2005 in the population in general of individuals who consumed crack at least once in life, which corroborate his statement ${ }^{(14)}$ 
The culture of crack use has changed in relation to usage patterns and even though most users consume it compulsively, some cases in this study revealed the existence of controlled use, which deserves to be better detailed, especially in relation to the strategies used to achieve $i^{(4)}$. However, it is worth noting that the urge for crack can encourage users to commit illegal activities, intensifying the process of social marginalization and risk posed to their freedom, as well as their physical, psychological and moral integrity(4).

Identifying the sequence of stages of drug use within the population and what influences it can be an efficient tool not only to understand this phenomenon but, moreover, to limit the increasing exposure to the risk of an escalating use of drugs ${ }^{(15)}$.

The initiation into the use of drugs by means of legal substances reported by users is similar to the results found in a study whose objective was to identify, among crack users, how the use of drugs progresses and what factors influence $i^{(15)}$. Two distinct phases were observed in the use of drugs. The first is related to legal drugs. Smoking and alcohol are the most reported. The second refers to the use of illegal drugs. In these cases, the interviewees' relatives and friends were the ones encouraging the consumption, and the reason alleged for the use of these substances was the need to acquire self-confidence. According to the results, early age and the heavy use of one or more drugs determined the beginning of an escalation to illegal drugs.

The report of undertaking illegal activities to acquire crack is frequent in the social context of users. Given the urge for drugs and a lack of financial means to acquire it, users see themselves as being "forced" to participate in illegal activities such as drug traffic, burglary, or robbery, among others ${ }^{(2,4)}$.

In a study developed with crack users hospitalized in the São Pedro Psychiatric Hospital, Porto Alegre, RS, Brazil revealed that the presence of criminal antecedents was observed in $40 \%$ of the sample, while such a behavior was related more to anxiety, depression and craving(16).

The spontaneous search on the part of users for chemical dependency treatment is worth noting, especially due to the fact that crack is considered a highly addictive drug with negative consequences for the individual and collective spheres. It was possible to perceive in some individuals that the search for care emerged as a way to "alleviate" the long periods of drug use in the streets, without evidence that there is a real motivation to cease its use.
Considering the role of the family and family bonds in nurturing resilience in individuals to cope with hardships ${ }^{(9)}$, we verified that the studied group experienced various unfavorable events that may have acted as an inducement to the beginning of drug use: disease in the family, especially the use of alcohol and drugs; fighting and separation of spouses; interfamily physical and psychological violence; and the rupture of relational bonds with the family and social milieu.

The family is considered one of the strongest links in the multifaceted chain that may lead to the use of alcohol and drugs, and also acts as an important protection factor ${ }^{(17-18)}$. This is explained by the fact that the consumption of psychoactive drugs is predominantly learned through interactions established between individuals and their primary sources of socialization, which in Western civilization includes the family, school, and group of friends. The result of this constant interaction is the establishment of a bond that permits the communication of a set of rules ${ }^{(17)}$.

The way one is raised by family is essential in one's development. It is the responsibility of parents to protect children from risk factors related to drugs ${ }^{(18)}$. A favorable environment for the consumption of psychoactive substances is influenced by many factors, and the family is the most important one ${ }^{(19)}$. Lack of parental support, the use of drugs by the parents themselves, permissive behavior of parents in the face of consumption, and an inability of parents to control their children are factors that predispose them to initiate or continue the use of drugs ${ }^{(20)}$.

In relation to an absence of a relationship with the parents, the situation worsens with increased chemical dependency generated by the use of crack, in which the rupture of character leads the user to use illegal means with the family; recurrent lies, robbery inside the home, and violence are common among dependents ${ }^{(2,4)}$. Consequently, there is a loss of family reference, with work and school; situation verified in most of the studied cases.

The diversity of social configurations expressed by dependency on crack is also worth noting. There are some users with more than five years of consumption, with a pattern of use associated with other drugs in which being marginalized is not common. In these cases, the individuals manage to keep jobs and family bonds(13,21).

In relation to the family domain and its influence on the use of psychoactive substances during adolescence, the following protection factors against the use of drugs stand out: establishment of strong bonding between parents and children, the creation of rules and 
the imposition of clear and coherent limits in addition to monitoring, supervising and supporting young individuals' attitudes and decision-making, and adopting dialog as a common practice in the family routine ${ }^{(5)}$.

The importance of the family's participation in the behavior of individuals in relation to the use of drugs is evidenced in this study. However, this importance is the result of the relationships and bonds established with families over the long process of growing up and emotional maturation of these individuals.

The use of drugs by the parents and other family members is certainly one of the great influences on adolescents becoming drug dependent themselves. The inter-generational transmission of behavioral patterns is frequently addressed in the literature; parents who use some kind of drug serve as models for their children's experimentation and continuity of alcohol and other drug consumption ${ }^{(5,7,20)}$.

This perspective allows us to better understand some phenomena such as when in a family composed of father, mother and children, only one of the children becomes drug dependent. However, it is important to note that in some cases, the event 'drugs' may interfere, influence or be part of the process of one's individualization, meaning that each one adopts different behavior in relation to an apparently similar event ${ }^{(22)}$.

Interfamily violence, evidenced in the studied cases, is defined as "[...] every action or omission that harms one's well-being, physical or psychological integrity or the freedom and right to full development. It may be committed inside or outside the home by some family member, including people who assume the parental role, even without blood ties, and in a relationship of power" (23).

Child sexual abuse reported by one user is a problem that involves issues of legal protection for the child and punishment for the aggressor, and also therapeutic care for the child's physical and mental health given the psychological consequences accruing from a situation of abuse. Such consequences are directly related to factors such as: the child's age and the duration of abuse; conditions in which it occurs, whether it involves physical violence and threats; degree of relationship with the abuser; and absence of protective parental figures. These factors may also be associated with deviation of behavior during adulthood and the use of drugs ${ }^{(24)}$.

\section{Conclusion}

The investigated cases revealed loss of relational bonds with the family and social milieu, and the use of drugs and violence within the family environment.
Further research is required to advance knowledge and practice related to the use of crack, aiming to establish ties with families in order to identify their traditions, values and customs because families play an essential role in preventing and treating drugs use.

It is also important to consider that many users do not have (or never had) a properly organized family context. In these cases, the work of health professionals is essential, especially in the case of those included in the primary health care sphere, in order to identify these users and refer them to appropriate health care.

Even though a topic of this nature is cross-sectional to any profession, professionals in the health field and even human sciences should appropriate from this discussion because there is an urgent need to establish a link with nursing care, which has an educational role as one of its main guiding axes. These professionals can contribute to identifying and implementing preventive actions, especially those working in the Family Health Strategy, given their proximity to and familiarity with the families.

Finally, the absence of social support- understood here as having a job, family stability, and the availability of appropriate care network-and the deficient access and lack of bonds with primary health care service, which is not very accessible to the most needy, has currently aggravated the situation of crack consumption.

The Brazilian Single Health System has faced an increased number of users seeking treatment, which requires a structured network of psychiatric care ensuring continuity of care whenever necessary. The redefinition of the care model directed to mental health has been an advancement seeking to avoid patients being excluded from society. However, Brazil has not been able to create appropriate substitute services in a quantity compatible with the demand for these services.

\section{References}

1. Dunn J, Laranjeira RR, Da Silveira DX, Formigoni ML, Ferri CP. Crack cocaine: an increase in the use among patient attending clinics in São Paulo 1990-1993. Subst Use Misuse. 1996;31(4):519-27.

2. Oliveira LG, Nappo AS. Avaliação da cultura do uso de crack após uma década de introdução da droga na cidade de São Paulo [tese]. São Paulo: Escola Paulista de Medicina, Universidade Federal de São Paulo; 2007. $330 \mathrm{p}$.

3. Oga S, Carvalho MMA, Batistuzzo JAO. Fundamentos de Toxicologia. 3a ed. São Paulo: Atheneu; 2008. 696 p. 
4. Oliveira LG, Nappo AS. Caracterização da cultura de crack na cidade de São Paulo: padrão de uso controlado. Rev Saúde Pública. 2008;42(4):664-71.

5. Schenker M, Minayo MCS. Fatores de risco e de proteção para o uso de drogas na adolescência. Cienc Saúde Colet. 2005;10(3):707-17.

6. Elsen I. Cuidado familial: uma proposta inicial de sistematização conceitual. In: Elsen I, Marcon SS, Silva MRS, organizadoras. O viver em família e sua interface com a saúde e a doença. $2^{a}$ ed. Maringá: Eduem; 2004. $398 \mathrm{p}$.

7. Medina NA, Ferriani MGC. Protective factors for preventing the use of drugs in the families of a Colombia locality. Rev. Latino-Am. Enfermagem. 2010;18(Spec):504-12.

8. Osório LC, Valle MEP, organizadores. Manual de terapia familiar. Porto Alegre: Artmed; 2009.

9. Bernardy CCF, Oliveira MLF. O papel das relações familiares na iniciação ao uso de drogas de abuso por jovens institucionalizados. Rev ESC Enferm USP. [periódico na Internet]. 2010; 44(1):11-7.

10. Marcílio C. Dicionário de pesquisa clínica. Salvador: Artes Gráficas; 1995.

11. Thiollent M. Metodologia da pesquisa-ação. $13^{a}$ ed. São Paulo: Cortez; 2004.

12. Minayo MCS, organizadora. Pesquisa social: teoria, método e criatividade. 24aed. Petrópolis: Vozes; 2010.

13. Duailib LB, Ribeiro M, Laranjeira R. Profile of cocaine and crack users in Brazil. Cad Saúde Pública. 2008; 24 (Suppl 4):545-57.

14. Centro Brasileiro de Informações sobre Drogas Psicotrópicas (Cebrid). II Levantamento domiciliar sobre o uso de drogas psicotrópicas no Brasil: estudo envolvendo as 108 maiores cidades do país. São Paulo: Cebrid - Centro Brasileiro de Informações sobre Drogas Psicotrópicas e Unifesp - Universidade Federal de São Paulo; 2007.

15. Sanchez ZVDM, Nappo AS. Sequência de drogas consumidas por usuários de crack e fatores interferentes. Rev Saúde Pública. 2002;36(4):420-30.

16. Guimarães CF, Santos DVV, Freitas RC, Araújo RB. Perfil do usuário de crack e fatores relacionados à criminalidade em unidade de internação para desintoxicação no Hospital Psiquiátrico São Pedro de Porto Alegre (RS). Rev Psiquiatr Rio Gd Sul. 2008;30(2):101-8.

17. Paiva FS, Ronzani TM. Estilos parentais e consumo de drogas entre adolescentes: revisão sistemática. Psicol Estud. 2009;14(1):177-83.
18. Schenker M, Minayo MCS. A implicação da família no uso abusivo de drogas: uma revisão crítica. Cienc Saúde Colet. 2003;8(1):299-306.

19. Mombelli MA, Marcon SS, Jaquilene B. Caracterização das internações psiquiátricas para desintoxicação de adolescentes dependentes químicos. Rev Bras Enferm. [periódico na Internet]. 2010;63(5):735-40.

20. Bahr SJ, Hoffmann JP, Yang. Parental and peer influences on the risk of adolescent drug use. J Prim Prev. 2005;26(6):529-51.

21. Kessler F, Pechansky FHP. Uma visão psiquiátrica sobre o fenômeno do crack na atualidade. Rev Psiquiatr Rio Gd Sul. 2008;30(2):96-8.

22. Caldeiras ZF. Drogas, indivíduo e família: um estudo de relações singulares. [dissertação]. Escola Nacional de Saúde Pública: Fundação Oswaldo Cruz; 1999.

23. Ministério da Saúde (BR). Violência intrafamiliar: orientações para a prática em serviço. Brasília; 2001. p. 15.

24. Araújo MF. Violência e abuso sexual na família. Psicol Estud. 2002;7(2):3-11.
Received: Oct. $2^{\text {nd }} 2010$ Accepted: Ago. 10 2011 